\title{
John Hope Franklin, Legal Scholar and Teacher
}

On March 25, 2009, John Hope Franklin died of congestive heart failure at the age of ninety-four. Obituary notices and magazine articles appeared across the country, eulogizing his public career, his academic career, and his scholarly career, but little was said concerning his writings and teachings about the law. Among his many interests and publications, however, and perhaps closest to his heart, was history of the law and how the laws worked in practice. From the beginning of his career he emphasized how African Americans were forced to struggle against specific state statutes and federal codes designed to regulate their movements, curtail their activities, and deny them equal rights. In fact, they were the only group in U.S. history, except for the Chinese, under Exclusion Act in 1882, who confronted such laws. In his doctoral dissertation, The Free Negro in North Carolina, 1790-1860, completed in 1941 and published by the University of North Carolina Press in 1943, he devoted fully one-fourth of the 226 pages of text to the "Legal Status of the Free Negro," discussing a broad range of legal and constitutional issues to show how free blacks could be sold as slaves, arrested for entering the state, jailed for traveling without papers, and denied full citizenship. Yet, they were not denied a trial by jury, or access to legal counsel, and prior to 1835 , they could vote in state and local elections. Among Franklin's more than twenty books written or edited perhaps none is more important than From Slavery to Freedom: A History of African Americans, the first edition published in 1947 by Alfred A. Knopf. Now in its eighth edition and having sold 3.5 million copies and translated into five languages, From Slavery to Freedom discusses many aspects of legal history, from the Black Codes in the Caribbean and South America, to laws and regulations in colonial America, the conflicts between the ideals of liberty and the defense of human bondage during the American Revolution, and the "Conservative Reaction" at the Constitutional Convention. The Founding Fathers, Franklin asserted, not only condoned the "peculiar institution" but also prolonged the Atlantic Slave trade for twenty years and permitted slave owners to retrieve their human property. "No Person held to Service or Labour in one state, under the Laws thereof, escaping to another, shall, 
in Consequence of any Law or Regulation therein, be discharged from such Service or Labor, but shall be delivered upon on Claim of the Party to whom such Service or Labor may be due." Franklin also analyzed the great variety of state laws during the slavery era and afterwards, the legal and constitutional changes that occurred as a result of the Civil War, including the Thirteenth (freedom), Fourteenth (citizenship) and Fifteenth (franchise) Amendments, and the Jim Crow legislation of the late nineteenth and early twentieth centuries, a period he and other historians termed the nadir in African American history following Emancipation. He also analyzed the impact of twentieth-century Supreme Court decisions and congressional legislation concerning civil rights and voting privileges.

Over the years, Franklin also included discussions of these and other related subjects in several books, including The Emancipation Proclamation (1963), Racial Equality in America (1976), and The Color Line: Legacy for the Twenty-first Century (1993). His articles included "African-Americans and the Bill of Rights in the Slave Era," "History of Racial Segregation in the United States," "Civil Rights in American History," and "The Enforcement of the Civil Rights Act of 1875." In 1995, with a former student at the University of Chicago, Jenna Rae McNeil, Franklin edited a volume titled African Americans and the Living Constitution, discussing legal issues from the time of the Founding Fathers to Brown v. Topeka Board of Education in the mid-twentieth century to current issues. In the final section, A. Leon Higginbotham Jr., Thurgood Marshall, and Julius L. Chambers ponder questions about what it has meant for the country to have laws and Supreme Court decisions that deny equal rights and justice to a particular group of people.

Franklin's legal writings also included participation in two court cases, including the case many believe to be one of the most important Supreme Court opinions in U.S. history. Having experienced racial segregation in his native state of Oklahoma, as student at Harvard University, and in the North and South, he felt strongly about seeking to correct the injustices done to African Americans. In 1949, he assisted Thurgood Marshall and the NAACP Legal Defense Fund in preparing background information in the Lyman Johnson v. University of Kentucky case involving the "separate but equal" clause in the U.S. Supreme Court opinion of Plessy v. Ferguson fifty-three years before. Johnson was denied admission to the University of Kentucky's graduate history program because, university officials asserted, the Kentucky State College for Negroes offered him an equal opportunity for advanced training. In his analysis, Franklin compared the two institutions, showing that such an assertion was based on race rather than any objective comparison of the two programs. In the summer of 1953, following the Supreme Court's deferred judgment of five cases challenging racial segregation in elementary and high schools, Franklin 
again assisted Marshall in preparing historical background information. Now he prepared a monograph on, as he put it, the way in which the Americans "defied, ignored, and worked against every conception of equality laid down in the Fourteen Amendment and subsequent legislation." It was used in the final NAACP brief in what became the landmark 1954 case of Brown v. Board of Education of Topeka, ending segregation in the public schools.

Although more difficult to quantify than his books, articles, essays, and legal briefs, Franklin also made a significant contribution as a teacher of the law. Indeed, if someone were to ask him what he considered his most important legacy, it would undoubtedly be his work as a historian, scholar, and teacher. His legacy as a teacher was truly exceptional, with literally thousands of students over the years at many colleges and universities, not only where he taught for a number of years (St. Augustine, North Carolina College for Negroes, Howard, Brooklyn College, University of Chicago, Duke) but also where he taught for a semester or quarter or as visiting professor, including the University of Maryland, Harvard, University of California at Berkeley, University of Wisconsin, Cambridge University, among others. He taught undergraduates throughout his career, including his tenure at the University of Chicago, where he directed thirty-four doctoral dissertations, and following his "retirement" as the James B. Duke Distinguished Professor at Duke University. His teaching career spanned fifty-six years, beginning as a oneyear temporary replacement for his mentor Theodore Currier at Fisk University in 1936 (to repay a loan from Currier and save enough to return to Harvard) and ending in 1992, after seven years teaching a popular course in Duke Law School with historian William Leuchtenburg and legal scholar Walter Dellinger. Over the years, he discussed the law and constitutional history in all of his classes and commented toward the end of his life that his teaching career would not have been complete without his stint at the Duke Law School.

Thus, despite his many contributions, John Hope Franklin's emphasis on the importance of the law, not only as means of governing our lives but as a reflection of our society, has assisted Americans in providing, as the title of his autobiography says, a Mirror to America.

\section{Loren Schweninger}

Elizabeth Rosenthal Excellence Professor

University of North Carolina at Greensboro 